\title{
Analysis of Quality Factors of Service to Patient Recommendations at Pondok Indah Bintaro Jaya Hospital
}

\author{
Tukhas Shilul Imaroh ${ }^{1}$, Nunie Nurida ${ }^{2}$ \\ ${ }^{1}$ Universitas Mercu Buana, Jakarta, Indonesia \\ ${ }^{2}$ Institut Teknologi Indonesia, Serpong, Indonesia \\ Corresponding Author: Tukhas Shilul Imaroh
}

\begin{abstract}
The health industry from year to year experiences continuous development, this causes competition to maintain and increase the quantity of patients becomes increasingly difficult. Pondok Indah Bintaro Jaya Hospital as one of the industries engaged in health care services feels the impact of this health care industry competition. This study aims to determine the factors that influence the quality of service (SERVQUAL) and its influence on patient recommendations at Pondok Indah Bintaro Jaya Hospital. Respondents of this study were the patients of Pondok Indah Bintaro Jaya Hospital with the number of research respondents set at 99 respondents. This research was included in the survey method, where the data collection instrument was carried out using a five-dimensional quality service questionnaire which was measured based on the patient's perceptions and expectations using a 4-point Likert scale about the overall quality of service that was felt by patients at Pondok Indah Bintaro Jaya Hospital. This study uses Partial Least Square (PLS) analysis with the help of the PLS 3.2.7 software program as an analytical tool and the sampling method uses a stratified purposive sampling. The results of this study can be seen that patients who recommend the Hospital feel satisfied with the services provided, especially in terms of Assurance and Tangibles. But overall that (Y1) Quality of Service has a positive or significant direct effect on (Y2) Recommendation of patients with a value of 0.571 . This indicates that patients who seek treatment and use Pondok Indah Bintaro Jaya Hospital Services feel Satisfied with all the services that have been given and will
\end{abstract}

recommend services that have been felt to others.

Keywords: SERVQUAL, Service Quality and Patient Recommendations.

\section{INTRODUCTION}

Currently the hospital continues to grow rapidly, both in number, capacity and infrastructure along with technological developments. Although there are developments in the basic functions of a hospital, it remains unchanged, namely restoring the health of community members, both inpatient and outpatient services, as well as consultation on the maintenance or health care of community members. Therefore we need the right strategy in managing health services in hospitals. Pondok Indah Bintaro Jaya Hospital continues to strive to be able to improve services to satisfy patients and build loyalty. The factors affecting patient loyalty in this study are limited to patient satisfaction with the Service Quality (SEVQUAL).

The standard value or ideal number that should be achieved refers to the Indonesian Ministry of Health standard, namely $60-85 \%$. The low level of BOR (Bed Occupancy Rate) achieved actually shows that the quality of service at the hospital concerned is not good. If the BOR (Bed Occupancy Rate) is low and ALOS (Average Length of Stay) is high, it means that the hospital service is bad. 
Tukhas Shilul Imaroh et.al. Analysis of quality factors of service to patient recommendations at Pondok Indah Bintaro Jaya Hospital.

Table 1. Number of Patient Visits in 2017

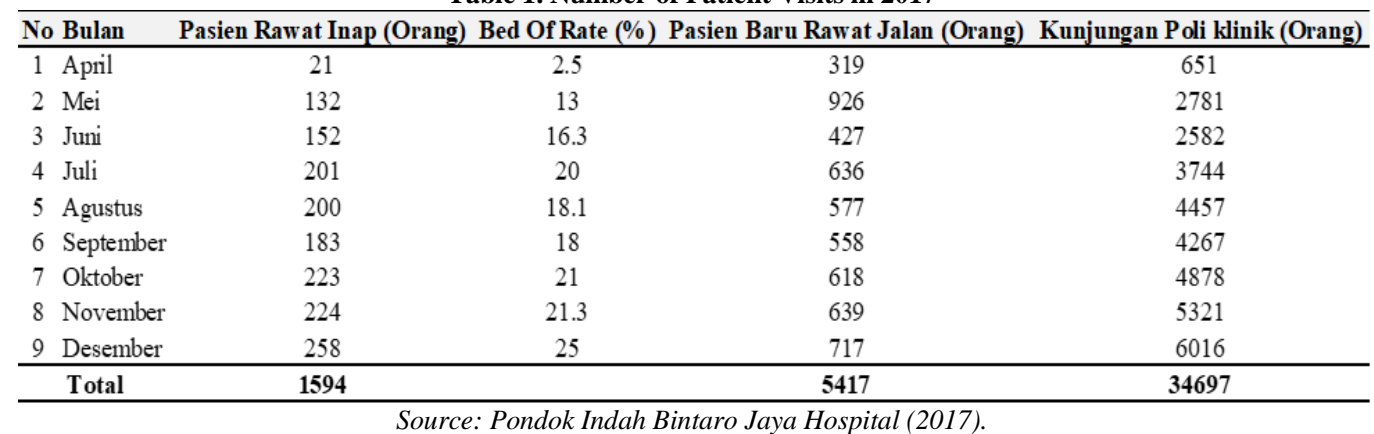

Table 2 and Graph 1. Number of Patients in 2017

\begin{tabular}{|c|c|c|c|c|}
\hline Nama Rumah Sakit & Kelas & Rawat Jala & Rawat Inap & IGD \\
\hline 1 RS Premiere Bintaro Jaya & $B$ & 189790 & 14746 & 24547 \\
\hline 2 RSEka & B & 197498 & 8341 & 15943 \\
\hline 3 RSOmi & B & 135195 & 10556 & 10556 \\
\hline 4 RS Medika BSD & B & 0 & 2553 & 2553 \\
\hline 5 RS Sari Asih Ciputat & B & 140249 & 14476 & 35102 \\
\hline 6 RS Pondok Indah Bintaro Jay; & B & 34697 & 1594 & 5721 \\
\hline
\end{tabular}

GRAFIK JUMLAH PASIEN TAHUN 2017

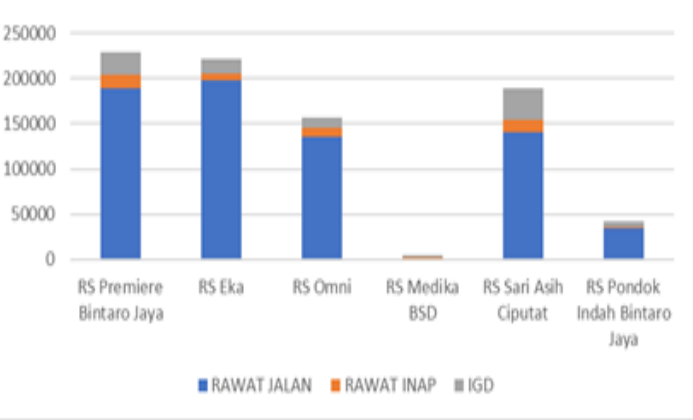

Figure 1. Number of patients in 2017

Table 3 and Graph 2. Hospital Service Indicators in 2017

\begin{tabular}{lcccccc}
\hline $\mathrm{N}_{0} \quad$ Nama Rumah Sakit & \multicolumn{6}{c}{ KELAS BOR ALOS TOI NDR GDR } \\
\hline 1 RS Premiere Bintaro Jaya & B & 62 & 3 & 2 & 5 & 11 \\
\hline 2 RS Eka & B & 62.35 & 3.5 & 3.5 & 1 & 1.47 \\
\hline 3 RS Omi & B & 67.6 & 2.9 & 2.9 & 0.4 & 0.9 \\
\hline 4 RS Medika BSD & B & 37 & 3.4 & 0 & 0 & 0 \\
\hline 5 RS Sari Asih Ciputat & B & 83.4 & 3.6 & 0 & 9 & 0 \\
\hline 6 RS Pondok Indah Bintaro Jaya & B & 17.8 & 3.1 & 19.3 & 0 & 0.1 \\
\hline \multicolumn{2}{c}{ Sourcer: Kemkes.go.id (2017), }
\end{tabular}

The table above shows that the BOR (Bed Occupancy Rate) indicator is still below the ideal value, namely the average
GRAFIK INDIKATOR PELAYANAN RUMAH SAKIT TAHUN 2017

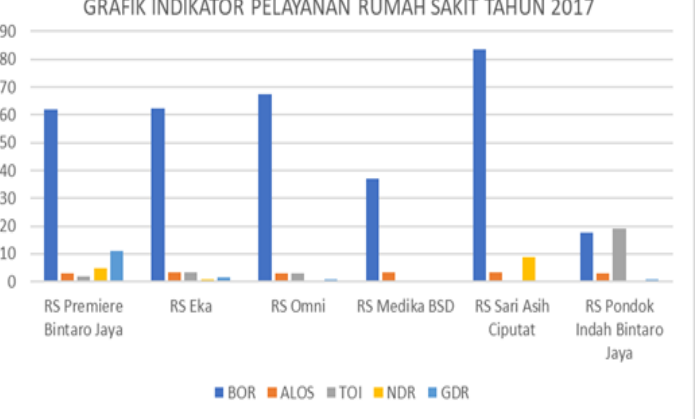

Figure 2. Hospital Service Indicators (2017)

for the last 9 months of $17.8 \%$ whereas according to the ideal value set by the Ministry of Health it is $60-85 \%$.

Table 4. Number of Repeating Complaints Table

\begin{tabular}{ccccccccccc}
\hline BULAN & \multicolumn{1}{c}{ APRIL MEI JUNI JULI AGUSTUS SEPTEMBER OKTOBER NOVEMBER DESEMBER TOTAL } \\
\hline $\begin{array}{c}\text { JUMLAH KOMPLAIN } \\
\text { TERULANG }\end{array}$ & 3 & 7 & 5 & 7 & 3 & 4 & 5 & 10 & 17 & 61 \\
\hline \multicolumn{1}{c}{ Source: Pondok Indah Bintaro Jaya Hospital (2017). }
\end{tabular}

Based on these data, there are still several complaints from patients and their families that have been received by the hospital, either directly or indirectly. In general, the patient's shortcomings or complaints include:

Realiability: The administration process tends to be slow, more than 5 minutes and still finds nurses and doctors who are not arriving on time, so patients who need to wait. Assurance (Guarantee): There are still errors of doctors in patient examination and inaccuracy of nurses in re-checking the suitability of patient data. Tangible (Physical Evidence): There were still garbage found in the waiting room left by 
visitors and the patient's room which was not tidy when the patient entered and employees who were not wearing official uniforms were still found according to the set schedule. Empathy: There are still unfriendly admissions employees, this can be seen from the way they speak harshly when serving patients. Responsive: Doctors have not yet maximally provided services, such as the absence of doctors at the service center when patients need them, and there are still nurses who have long responded to patient complaints and are less dexterous in responding to patient requests. Based on the description above, it is necessary to conduct a study to determine the factors that cause patient dissatisfaction with the services received from the hospital. To test this research, the Structural Equation Modeling (SEM) method is used.

The purpose of this study was to analyze the effect of Reliability on service quality, Assurance on service quality, Tangibles on service quality, Empathy for service quality, Responsiveness on service quality, and service quality on patient recommendations.

\section{LITERATURE REVIEW}

According to Parasuraman et al (Muninjaya, 2011) 1) Service Quality is the difference between the service expected and the service received. The quality of service provided to consumers must function to provide more maximum satisfaction, therefore in order to provide services must be carried out in accordance with the service function. Service quality needs to be measured for at least three reasons (A. Brysland and A. Curry, 2001) 2), namely: Analyzing the effect of Reliability (reliability) on service quality, Assurance (guarantee) on service quality, Tangibles (tangible form) on service quality, Empathy (empathy) on service quality, Responsiveness (responsiveness) to service quality, and service quality to patient recommendations .

1) The measurement results can be used to make comparisons between before and after a change in policy in an organization.

2) Measurement is needed to find the location of problems related to service quality.

3) The measurement results are needed to establish quality service standards

\section{Quality of Hospital Services}

To determine the level of utilization, quality and efficiency of hospital services, various indicators are needed. In addition, in order for the information to be meaningful there must be a parameter value that will be used as a comparison value between the facts and the desired standard. Based on the national health service measurement standards (Depkes 2015), the following indicators are sourced from the daily census of inpatients:

Bed Occupancy Rate (BOR), Yaitu presentase pemakaian tempat tidur pada satu satuan waktu tertentu. Indikator ini memberikan gambaran tinggi rendahnya tingkat pemanfaatan dari tempat tidur rumah sakit. Nilai parameter dari BOR ini idealnya antara $60-85 \%$.

\begin{tabular}{|c|}
\hline BOR : \\
Jumlah hari perawatan rumah sakit \\
\hline Jum TT $\times$ Jumlah hari dalam satu satuan waktu
\end{tabular}

Average Length of Stay (ALOS), That is the average length of stay for a patient. This indicator in addition to providing an overview of the level of efficiency can also provide an overview of the quality of service, if applied to certain diagnoses that are used as tracers (which need further observation). In general, the ideal LOS is $<12$ days.

\begin{tabular}{|c|c|}
\hline \multirow{2}{*}{ ALoS: } & Jumlah hari lama dirawat pasien keluar \\
\hline & Jumlah pasien keluar (hidup + mati) \\
\hline
\end{tabular}

Turn Over Interval (TOI), That is, on average days, the bed is not occupied from the time it is filled to the next time it is filled. Ideally the bed is empty in only 1-3 days.

\begin{tabular}{|c|c|}
\hline & (Jumlah TT x hari) - hari perawatan rumah sakit \\
\hline & Jumlah pasien keluar (hidup + mati) \\
\hline
\end{tabular}


Net Death Rate (NDR), Namely the mortality rate 48 hours after being treated for every 1000 patients discharged. This indicator can provide an overview of the quality of service in the hospital. The NDR value that was considered tolerable was less than 25 per 1000 patients discharged.

\begin{tabular}{|c|}
\hline Jumlah pasien mati $\geq 48$ jam dirawat \\
JDR: \\
Jumlah pasien keluar (hidup + mati)
\end{tabular}

Gross Death Rate (GDR), That is the general mortality rate for every 1000 patients who come out. The GDR value should not be more than 45 per 1000 patients discharge.

\begin{tabular}{|lll|}
\hline \multirow{2}{*}{ GDR: } & Jumlah pasien mati seluruhnya & \\
& Jumlah pasien keluar (hidup + mati) & \\
\hline
\end{tabular}

\section{Service Quality}

Rambat Lupiyoadi in his book Service Marketing Management (2013: 212) 3 ) defines, product (service) quality is the extent to which the product (service) meets its specifications.

\section{Service Quality Dimensions}

Through a series of studies on various kinds of service industries according to Parasuraman, Zeithaml, and Berry in Fandy Tjiptono (2012: 196) 4) identified 10 dimensions of service quality:

1) Reliability; includes consistency of performance and reliability. This means that the organization shows immediate service and means that the organization respects its promises. This includes; accuracy of billing, keeping records properly, and accuracy of schedule.

2) Responsiveness; includes sending transaction slips promptly, dealing with customer responses quickly, providing preliminary services.

3) Competence; includes knowledge and expertise in personnel contacts, knowledge and expertise in operations support personnel, organizational research capabilities.

4) Access; includes services that are easily accessible by telephone (line not busy), short service waiting times, convenient operating hours and convenient location of service facilities.

5) Courtesy; includes friendliness, respect, consideration, and friendship in contact personnel (including receptionists, telephone operators). This includes; consideration of customer's personal belongings, clean and tidy appearance in service room.

6) Communication; includes an explanation of the service itself and an explanation of how much a service costs, a description of how the service and is usually exchanged, assuring the customer that the problem will be handled.

7) Credibility; includes trust, confidence, honesty. Includes the emergence of the condition that the customer's interest is everything. Contributors to credibility, among others; name of the organization, reputation of the organization, personal characteristics of the contacting personnel.

8) Security; is free from harm, risk, or doubt. This includes; physical security, financial security, confidentiality.

9) Understanding; includes making efforts to understand customer needs. Among others; understand customer special needs, provide personal attention, recognize regular customers.

10) Tangibles (Real Form); includes the physical appearance of the service; physical facilities, employee appearance, equipment used for services, physical representation of services, such as affidavits, other customers in service facilities.

In further research, Parasuraman, Zeithaml, and Berry in the Lupiyoadi Creep (2013: 216), found overlapping between the 10 dimensions above. Therefore, they simplify into five main dimensions of service quality (SERVQUAL), namely:

1) Reliability, namely the company's ability to provide services as promised accurately and reliably. Performance must be in accordance with customer 
expectations which means punctuality, the same service for all customers without errors, a sympathetic attitude, and with high accuracy

2) Assurance, namely the knowledge, politeness, and ability of company employees to foster customer trust in the company.

3) Tangibles), namely the ability of a company to show its existence to external parties. The appearance and ability of the company's physical facilities and infrastructure that can be relied upon by the condition of the surrounding environment is clear evidence of the services provided by service providers.

4) Empathy, which is giving sincere and individual attention to customers by trying to understand their desires.
5) Responsiveness, which is the company's ability to provide fast (responsive) and precise service to customers, by delivering clear information.

\section{Effect of Service Quality on Customer Satisfaction}

This study refers to previous research on "Analysis of the Effect of Service Quality on Quality and Patient Trust in Shanti Graha Buleleng General Hospital" by Kadek Brahma Shiro Wididana. (2017). The study was conducted to determine the effect of service quality on patient quality and trust. Respondents of this study were patients with a total of 140 respondents. In this study using partial least square (PLS) analysis with the help of the PLS 2.0 software program.

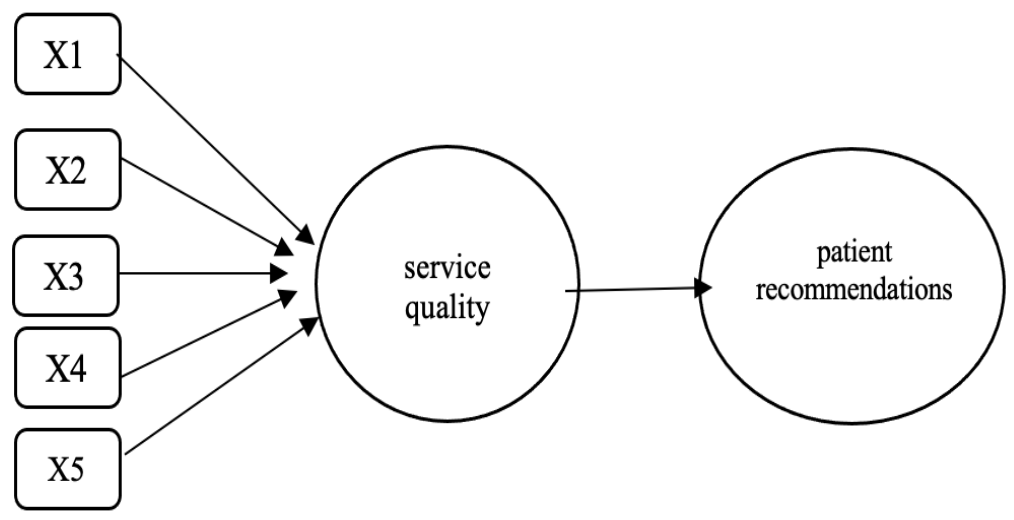

Figure 3. Frame Work

\section{Hypothesis}

The hypothesis in this study is formulated as follows:

1) Ho.1: Reliability does not have a significant effect on service quality and patient recommendations

2) Ha.1: Reliability has a significant effect on the quality of service and patient recommendations

3) Ho.2: Assurance does not have a significant effect on service quality and patient recommendations

4) Ha.2: Assurance has a significant effect on the quality of service and patient recommendations
5) Ho.3: Tangibles has no significant effect on service quality and patient recommendations

6) Ha.3: Tangibles have a significant effect on the quality of service and patient recommendations

7) Ho.4: Empathy does not have a significant effect on the quality of service and patient recommendations

8) Ha.4: Empathy has a significant effect on the quality of service and patient recommendations

9) Ho. 5: Responsiveness does not have a significant effect on service quality and patient recommendations 
10) Ha: 5: Responsiveness has a significant effect on the quality of service and patient recommendations

11) Ho. 6: Service quality does not have a significant effect on patient recommendations

12) Ha: 6: The quality of service has a significant effect on patient recommendations

\section{RESEARCH METHODS}

This research was conducted using a survey method. The population in this study were all patients and patient caregivers who performed or had been hospitalized at Pondok Indah Hospital, using the Slovin formula, the total sample was 99 inpatients. The verification analysis in this study used a statistical test tool, namely the variancebased structural equation test with Partial Least Square (PLS) using SmartPLS 3.2.7 software.

\section{RESULTS AND DISCUSSION Research Descriptive}

Respondents of this study were inpatients who had experienced health services at Pondok Indah Bintaro Hospital. The questionnaires distributed by researchers are offline questionnaires, tabulation of offline data that has been collected is 99, because the PLS SMART program only supports processing up to 99 data.

\section{Descriptive Respondents}

The table shows that the respondents who dominated this study were female respondents, as many as 52 people or with a percentage of $52 \%$ then male respondents as many as 47 people with a percentage of $47 \%$. For demographics based on age, it is dominated by respondents aged 26-35 years with a total of 44 and a percentage of $44 \%$, for 12-25 years old as much as 12 with a percentage of $12 \%$, for respondents aged 36-45 years as many as 19 people with a percentage of $19 \%$ then 11 respondents aged over 46 - 55 years with a percentage of $11 \%$ and aged 56-65 years as many as 8 people with a percentage of $8 \%$. For seniors aged 65 years and over there is 1 person with a percentage of $1 \%$, while for patients under five and children aged 0-11 years there are 4 people with a percentage of $4 \%$. Then from demographics based on the type of treatment that dominates are VIP patients, namely 65 respondents and a percentage of $65 \%$, class patients as many as 34 respondents with a percentage of $34 \%$, ICU patients as many as 2 respondents with a percentage of $2 \%$ and operating room patients (OT) as many as 2 respondents with a percentage of $2 \%$.

\begin{tabular}{|l|l|l|}
\hline CHARATERISTICS & TOTAL (PERSON) & PRESENTAGE \\
\hline GENDER & 47 & $47 \%$ \\
\hline Men & 52 & $52 \%$ \\
\hline Woman & \multicolumn{2}{|l|}{} \\
\hline AGE & $4 \%$ \\
\hline Toddlers \& Children = 0 - 11 years & 4 & $12 \%$ \\
\hline Early Adolescence = 12-25 years & 12 & $44 \%$ \\
\hline Early Adult = 26-35 years & 44 & $19 \%$ \\
\hline Late adult = 36- 45 years & 19 & 11 \\
\hline Early Elderly = 46- 55 years & 11 & $8 \%$ \\
\hline Late Elderly = 56 - 65 years & 8 & $1 \%$ \\
\hline Seniors = 65 - Onwards & 1 & \\
\hline TYPES OF CARE & 65 & $65 \%$ \\
\hline VIP & 34 & $34 \%$ \\
\hline Class & 2 & $2 \%$ \\
\hline ICU & 2 & $2 \%$ \\
\hline Operating Room (OT) & \\
\hline
\end{tabular}


Tukhas Shilul Imaroh et.al. Analysis of quality factors of service to patient recommendations at Pondok Indah Bintaro Jaya Hospital.
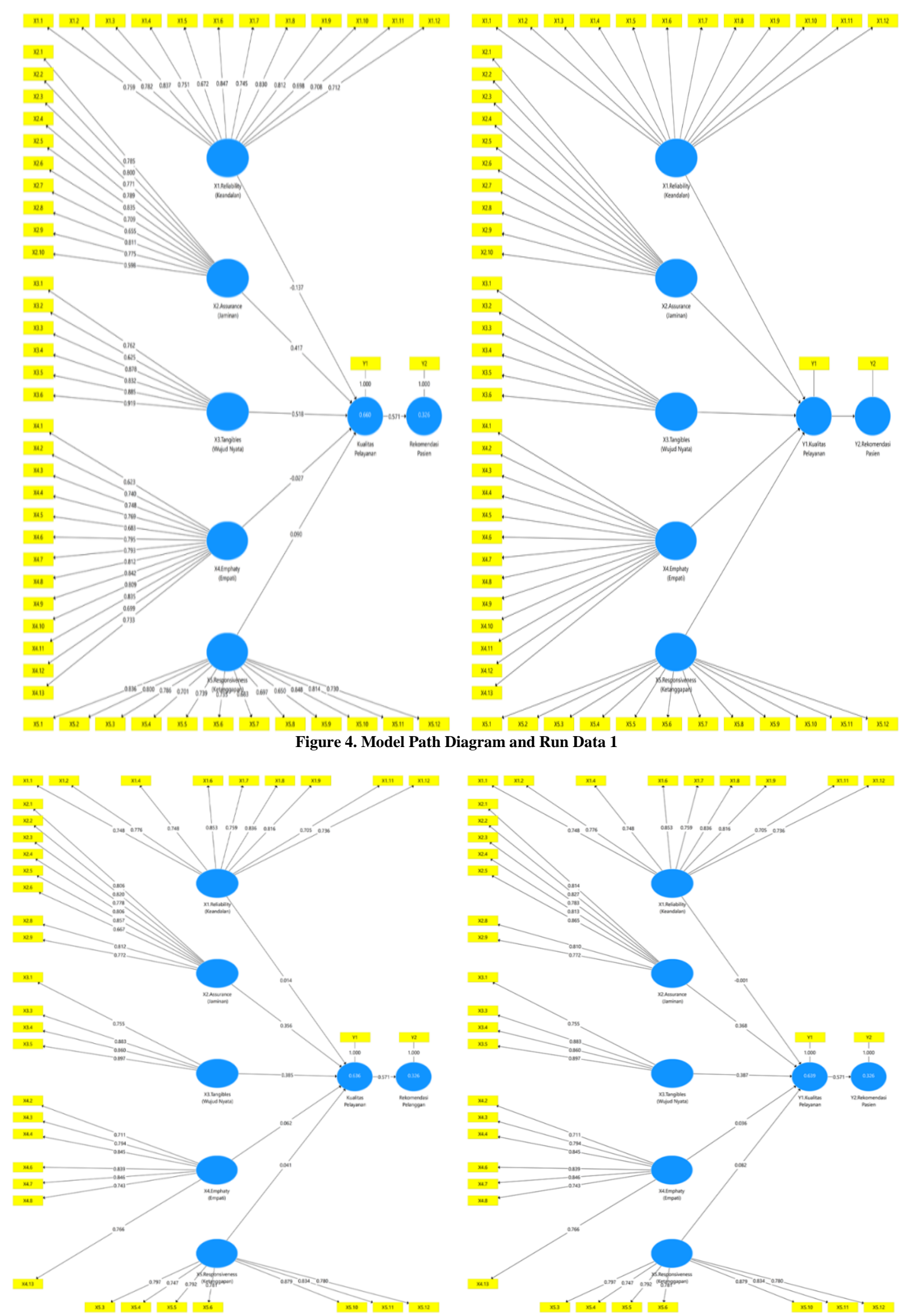

Figure 4. Path Diagram of PLS Algorithm Run Data 2 and 3, Source: Processed questionnaire data 


\section{Average Variance Extracted (AVE)}

Table 9. AVE Value of Measurement Model Construct Reliability and Validity

\begin{tabular}{lc}
\hline & Average Variance Extracted (AVF \\
\hline X1.Reliability (Keandalan) & 0.603 \\
X2.Assurance (Jaminan) & 0.660 \\
X3. Tangibles (Wujud Nyata) & 0.723 \\
X4.Empathy (Empati) & 0.630 \\
X5.Responsiveness (Ketanggapan) & 0.644 \\
Y1.Kualitas Pelayanan & 1.000 \\
Y2.Rekomendasi Pasien & 1.000 \\
\hline
\end{tabular}

Next is to assess the Average Variance Extracted (AVE), the AVE value used as a benchmark for assessing convergent validity is $>0.50$.

Based on the Table and Graph above, the measurement model in this study is said to be good because the AVE value for each latent variable is more than 0.5 and the measurement model has a factor loading value greater than 0.5 . The highest value of AVE is variable X3. Tangibles (Real Form) with a value of 0.723 . For the lowest value of AVE is X1. Reliability (Reliability) with a value of 0.603 .

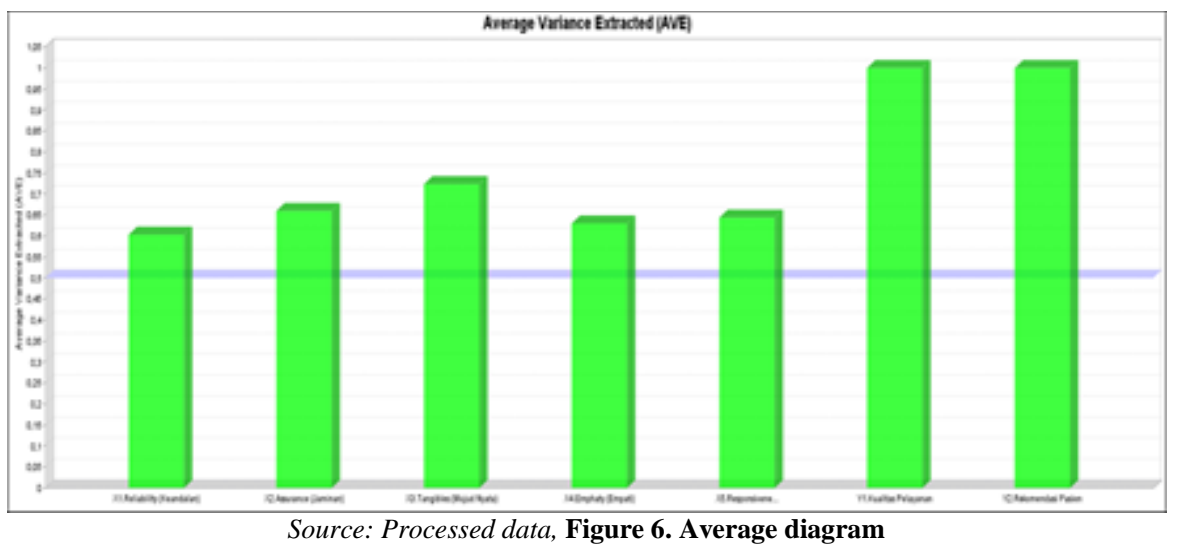

Discriminant validity test to see the correlation of indicators with latent variables. The test uses the cross loading value of the calculation results of the
SMART PLS application. The cross loading value for each variable must be> 0.70 . The discriminant validity test can be done in several ways, namely:

Table.10

\begin{tabular}{|c|c|c|c|c|c|c|c|}
\hline & $\begin{array}{l}\text { X1.Reliability } \\
\text { (Keandalan) }\end{array}$ & $\begin{array}{l}\text { X2.Assurance } \\
\text { (Jaminan) }\end{array}$ & $\begin{array}{l}\text { X3.Tangibles } \\
\text { (Wujud } \\
\text { Nyata) }\end{array}$ & $\begin{array}{c}\text { X4.Empathy } \\
\text { (Empati) }\end{array}$ & $\begin{array}{l}\text { X5.Responsiveness } \\
\text { (Ket anggapan) }\end{array}$ & $\begin{array}{l}\text { Y1.Kualitas } \\
\text { Pelayanan }\end{array}$ & $\begin{array}{l}\text { Y 2.Rekomend asi } \\
\text { Pasien }\end{array}$ \\
\hline $\mathrm{X} 1.1$ & 0.748 & 0.698 & 0.668 & 0.682 & 0.438 & 0.560 & 0.321 \\
\hline $\mathrm{X} 1.11$ & 0.705 & 0.570 & 0.463 & 0.612 & 0.786 & 0.451 & 0.255 \\
\hline $\mathrm{X} 1.12$ & 0.736 & 0.743 & 0.535 & 0.673 & 0.612 & 0.583 & 0.449 \\
\hline $\mathrm{X} 1.2$ & 0.776 & 0.735 & 0.678 & 0.715 & 0.556 & 0.629 & 0.398 \\
\hline $\mathrm{X} 1.4$ & 0.748 & 0.697 & 0.589 & 0.69 & 0.533 & 0.501 & 0.208 \\
\hline $\mathrm{X} 1.6$ & 0.853 & 0.854 & 0.664 & 0.835 & 0.606 & 0.665 & 0.333 \\
\hline $\mathrm{X} 1.7$ & 0.759 & 0.714 & 0.689 & 0.754 & 0.483 & 0.589 & 0.322 \\
\hline $\mathrm{X} 1.8$ & 0.836 & 0.708 & 0.61 & 0.729 & 0.824 & 0.598 & 0.396 \\
\hline $\mathrm{X} 1.9$ & 0.816 & 0.702 & 0.569 & 0.719 & 0.819 & 0.577 & 0.240 \\
\hline $\mathrm{X} 2.1$ & 0.800 & 0.814 & 0.711 & 0.815 & 0.539 & 0.651 & 0.380 \\
\hline $\mathrm{x} 2.2$ & 0.778 & 0.827 & 0.702 & 0.769 & 0.513 & 0.678 & 0.372 \\
\hline $\mathrm{X} 2.3$ & 0.720 & 0.783 & 0.512 & 0.678 & 0.562 & 0.672 & 0.502 \\
\hline $\mathrm{X} 2.4$ & 0.756 & 0.813 & 0.607 & 0.779 & 0.517 & 0.489 & 0.172 \\
\hline $\mathrm{X} 2.5$ & 0.813 & 0.865 & 0.701 & 0.776 & 0.524 & 0.607 & 0.385 \\
\hline $\mathrm{X} 2.8$ & 0.706 & 0.810 & 0.554 & 0.674 & 0.618 & 0.569 & 0.417 \\
\hline$\times 2.9$ & 0.671 & 0.772 & 0.587 & 0.673 & 0.575 & 0.579 & 0.467 \\
\hline $\mathrm{X} 3.1$ & 0.804 & 0.785 & 0.755 & 0.858 & 0.558 & 0.605 & 0.325 \\
\hline $\mathrm{X} 3.3$ & 0.639 & 0.614 & 0.883 & 0.589 & 0.465 & 0.597 & 0.284 \\
\hline $\mathrm{X} 3.4$ & 0.595 & 0.611 & 0.860 & 0.612 & 0.477 & 0.607 & 0.332 \\
\hline $\mathrm{X} 3.5$ & 0.642 & 0.623 & 0.897 & 0.611 & 0.414 & 0.711 & 0.318 \\
\hline $\mathrm{X} 4.13$ & 0.683 & 0.745 & 0.659 & 0.766 & 0.525 & 0.610 & 0.353 \\
\hline $\mathrm{X} 4.2$ & 0.642 & 0.568 & 0.475 & 0.711 & 0.774 & 0.503 & 0.293 \\
\hline $\mathrm{X} 4.3$ & 0.676 & 0.650 & 0.608 & 0.794 & 0.549 & 0.547 & 0.247 \\
\hline $\mathrm{X} 4.4$ & 0.811 & 0.822 & 0.762 & 0.845 & 0.538 & 0.634 & 0.358 \\
\hline $\mathrm{X} 4.6$ & 0.775 & 0.801 & 0.623 & 0.839 & 0.502 & 0.605 & 0.292 \\
\hline $\mathrm{X} 4.7$ & 0.803 & 0.834 & 0.691 & 0.846 & 0.550 & 0.635 & 0.304 \\
\hline $\mathrm{X} 4.8$ & 0.707 & 0.583 & 0.486 & 0.743 & 0.824 & 0.531 & 0.288 \\
\hline $\mathrm{X} 5.10$ & 0.750 & 0.652 & 0.530 & 0.755 & 0.879 & 0.547 & 0.348 \\
\hline X5.11 & 0.804 & 0.706 & 0.568 & 0.760 & 0.834 & 0.578 & 0.264 \\
\hline X5.12 & 0.672 & 0.550 & 0.432 & 0.600 & 0.780 & 0.450 & 0.279 \\
\hline X5.3 & 0.563 & 0.472 & 0.470 & 0.534 & 0.797 & 0.445 & 0.327 \\
\hline$\times 5.4$ & 0.457 & 0.358 & 0.296 & 0.382 & 0.747 & 0.349 & 0.268 \\
\hline X5.5 & 0.540 & 0.455 & 0.367 & 0.523 & 0.792 & 0.383 & 0.242 \\
\hline $\begin{array}{r}X 5.6 \\
\end{array}$ & 0.627 & 0.501 & 0.397 & 0.570 & 0.781 & 0.400 & 0.201 \\
\hline Y1 & 0.743 & 0.755 & 0.745 & 0.735 & 0.575 & 1.000 & 0.571 \\
\hline $\mathrm{Y} 2$ & 0.423 & 0.483 & 0.370 & 0.386 & 0.346 & 0.571 & 1.000 \\
\hline
\end{tabular}

Source: Processed data 
Cross loading, to test the validity of discriminant with reflexive indicators, by looking at the cross loading value for each variable must be> 0.70 . In table 10 , it can be seen that the model has good discriminant validity because the cross loading value for measuring its own construct is greater than the loading factor in measuring other constructs.

Square root Average Variance Extracted ( $\mathrm{AVE})$, Discriminant validity can be done by comparing the coefficient of AVE Root ( $\sqrt{A V E}$ or Squareroot Average Variance Extracted) of each variable with the correlation value between variables in the model. A variable is said to be valid, if the AVE root ( $\mathrm{AVE}$ or Squareroot Average Variance Extracted) is greater than the correlation value between variables in the research model> 0, 50 (Ghozali 2015: 74).

Table 11.

Discriminant Validity

\begin{tabular}{|c|c|c|c|c|c|c|c|}
\hline & $\mid \begin{array}{r}\text { Xl.Reliability } \\
\text { (Keandalan) }\end{array}$ & $\begin{array}{c}\text { X2.Assurance } \\
\text { (Jaminan) }\end{array}$ & $\begin{array}{c}\text { X3.Tangibles } \\
\text { (Wujud } \\
\text { Nyata) }\end{array}$ & $\begin{array}{c}\text { X4.Empathy } \\
\text { (Empati) }\end{array}$ & $\begin{array}{l}\text { X5.Responsiveness } \\
\text { (Ketanggapan) }\end{array}$ & $\begin{array}{l}\text { Yl.Kualitas } \\
\text { Pelayanan }\end{array}$ & $\begin{array}{c}\text { Y2.Rekomendasi } \\
\text { Pasien }\end{array}$ \\
\hline X1.Reliability (Keandalan) & 0.776 & & & & & & \\
\hline X2.Assurance (Jaminan) & 0.924 & 0.812 & & & & & \\
\hline X3.Tangibles (Wujud Nyata) & 0.786 & 0.772 & 0.851 & & & & \\
\hline X4.Empathy (Empati) & 0.921 & 0.909 & 0.782 & 0.794 & & & \\
\hline X5.Responsiveness (Ketanggapan) & 0.804 & 0.677 & 0.56 & 0.755 & 0.802 & & \\
\hline Y1.Kualitas Pelayanan & 0.743 & 0.755 & 0.745 & 0.735 & 0.575 & 1.000 & \\
\hline Y2.Rekomendasi Pasien & 0.423 & 0.483 & 0.370 & 0.386 & 0.346 & 0.571 & 1,000 \\
\hline
\end{tabular}

Table 12.

Square root Average Variance Extracted ( $\mathrm{AVE}$ )

\begin{tabular}{lcc}
\hline & $\begin{array}{c}\text { Average Variance } \\
\text { Extracted (AVE) }\end{array}$ & $\begin{array}{c}\text { Square root Average Variance } \\
\text { Extracted (VAVE) }\end{array}$ \\
\hline X1.Reliability (Keandalan) & $\mathbf{0 . 6 0 3}$ & 0.777 \\
X2.Assurance (Jaminan) & $\mathbf{0 . 6 6 0}$ & 0.812 \\
X3.Tangibles (Wujud Nyata) & $\mathbf{0 . 7 2 3}$ & 0.851 \\
X4.Empathy (Empati) & $\mathbf{0 . 6 3 0}$ & 0.794 \\
X5.Responsiveness (Ketanggapan) & $\mathbf{0 . 6 4 4}$ & 0.802 \\
Y1.Kualitas Pelayanan & $\mathbf{1 . 0 0 0}$ & 1.000 \\
Y2.Rekomendasi Pasien & $\mathbf{1 . 0 0 0}$ & 1.000 \\
\hline \multicolumn{3}{c}{ Source: Processed data }
\end{tabular}

Based on the table data above, the AVE value of all significant indicators is above 0.50 .

\section{Structural Model Analysis (Inner Model)}

The parameters used to evaluate the inner model in SmartPLS are the determinant coefficient (R2 test) and $\mathrm{t}$ value. The $\mathrm{R} 2$ value is used to measure how much the dependent variable can be influenced by the independent variable, while the t-value shows the significance of the influence between latent variables in the structural model on hypothesis testing. The inner model will see the relationship between constructs and the significance value as well as the Path coefficient and $R$ square values, the significance value is seen from the T-statistical value obtained by the Bootstrapping method in Smart PLS Software, and the path coefficient in the research model with a significance of $\alpha=$ $5 \%$.

Inner model evaluation can be seen from several indicators which include:

\section{The coefficient of determination (R2)}

Tabel 16.

Rule of Thumb Analisa Model Struktural (Inner Model)

\begin{tabular}{ll}
\hline \multicolumn{1}{c}{ Kretiria } & \multicolumn{1}{c}{ Rule of Thumb } \\
\hline R-Square & 0,$67 ; 0,33$ dan 0,19 menunjukkan model kuat, moderat, dan \\
& lemah \\
& t-value 1,65(signifikansi level 10\%); \\
Signifikansi (two-tailed) & t-value 1,96(signifikansi level 5\%); dan \\
& t-value 2,58 (signifikansi level 1\%). \\
\hline Sumber: Ghozali, 2014:81 &
\end{tabular}

The relationship between latent variables is said to be significant with a type error rate of 0.1 if it has a t-count greater than 1.65. The R-Squares value is a goodness fit model test. R-Squares value 0.67 ; 0.33 ; and 0.19 for the endogenous latent variables in the structural model shows a strong, moderate, and weak model (Chin, 1999 in Ghozali, 2014: 81).

Table 17.

\begin{tabular}{|l|l|l|}
\hline R Square & & \\
\hline & R Square & R Square Adjusted \\
\hline Y1 service quality & 0.639 & 0.620 \\
\hline Y2 patient recommendations & 0.326 & 0.319 \\
\hline Average R Square & 0.326 & 0.470 \\
\hline Source: Processed data & & \\
\hline
\end{tabular}




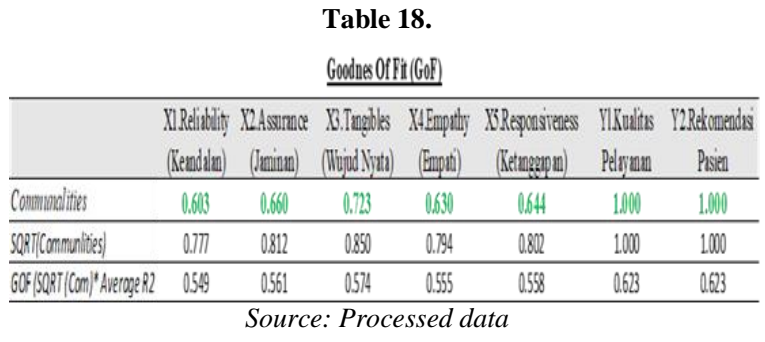

\section{Goodness of Fit Index (GoF)}

Nilai GoF ini diperoleh dari average communalities index dikalikan dengan nilai R2 model. Formula GoF index:

$$
\mathrm{GoF}=\sqrt{\overline{\mathrm{Com}} \times \overline{R^{2}}}
$$

The measurement value based on Goodness of Fit $(\mathrm{GoF})$ has a value range between 0 (zero) to 1 (one). The value of Goodness of Fit (GoF) which is getting closer to 0 (zero), shows that the model is getting less good, conversely, the farther away from 0 (zero) and closer to 1 (one), the better the model. The GOF value is obtained from the result of the communality root count multiplied by Average R2. GOF is said to be good if its value is smaller than 0.9 .

\section{Q Square Predictive Relevance (Q2)}

The result of Q2 predictive relevance is said to be good if the value> indicates that the exogenous latent variable is good (appropriate) as an explanatory variable capable of predicting the endogenous variable. The Q-Square Predictive Relevance (Q2) value ranges from 0 (zero) to 1 (one). The closer to 0 the value of Q-Square Predictive Relevance (Q2), provides a clue that the research model is getting worse, whereas on the other hand, the farther away from 0 (zero) and closer to the value 1 (one), this means that the research model is getting better.

The Q-Square formula is:

$\mathrm{Q} 2=1-(1-\mathrm{R} 12)(1-\mathrm{R} 22) \ldots(1-\mathrm{Rp} 2) \ldots$

$\mathrm{Q} 2=1-(1-0.639)(1-0.326)$

$\mathrm{Q} 2=\mathbf{0 . 7 5 7}$

From the results of the calculation of Q2 it is concluded that the amount of diversity of research data that can be explained by the structural model is $78 \%$ while the other $22 \%$ is explained by other variables.

\begin{tabular}{|c|c|c|}
\hline \multicolumn{3}{|c|}{$\begin{array}{l}\text { Table } 19 \\
\text { F SQUARE }\end{array}$} \\
\hline & Y1.Kualitas Pelayanan & Y2.Rekomendasi Pasien \\
\hline X1.Reliability (Keandalan) & 0.000 & \\
\hline X2.Assurance (Jaminan) & 0.041 & \\
\hline X3.Tangibles (Wujud Nyata) & 0.142 & \\
\hline X4.Empathy (Empati) & 0.000 & \\
\hline X5.Responsiveness (Ketanggapan) & 0.006 & \\
\hline Y1.Kualitas Pelayanan & & 0.484 \\
\hline Y2.Rekomendasi Pasien & & \\
\hline
\end{tabular}

This GoF value is obtained from the average communalities index multiplied by the R2 value of the model. GoF index formula:

The measurement value based on Goodness of Fit $(\mathrm{GoF})$ has a value range between 0 (zero) to 1 (one). The value of Goodness of Fit (GoF) which is getting closer to 0 (zero), shows that the model is getting less good, conversely, the farther away from 0 (zero) and closer to 1 (one), the better the model. The GOF value is obtained from the result of the communality root count multiplied by Average R2. GOF is said to be good if its value is smaller than 0.9 .

\section{Q Square Predictive Relevance (Q2)}

The result of Q2 predictive relevance is said to be good if the value> indicates that the exogenous latent variable is good (appropriate) as an explanatory variable capable of predicting the endogenous variable. The Q-Square Predictive Relevance (Q2) value ranges from 0 (zero) to 1 (one). The closer to 0 the value of Q-Square Predictive Relevance (Q2), provides a clue that the research model is getting worse, whereas on the other hand, the farther away from 0 (zero) and closer to the value 1 (one), this means that the research model is getting better.

The Q-Square formula is:

$\mathrm{Q} 2=1-(1-\mathrm{R} 12)(1-\mathrm{R} 22) \ldots(1-\mathrm{Rp} 2) \ldots$

$\mathrm{Q} 2=1-(1-0.639)(1-0.326)$

$\mathrm{Q} 2=0.757$

From the results of the calculation of Q2 it is concluded that the diversity of research data that can be explained by the structural model is $78 \%$ while the other $22 \%$ is explained by other variables. 


\section{F Square Effect Size}

The value of $\mathrm{f} 2$ can be interpreted whether the predictor variable has a weak, medium or large influence on the structural level. The formulation effect size $\mathrm{f} 2$ is:

$$
\text { Effect Size } \mathrm{f}^{2}=\frac{\mathrm{R}^{2} \text { Included }-\mathrm{R}^{2} \text { Excluded }}{1-\mathrm{R}^{2} \text { Included }}
$$

Where $\mathrm{R}$ included and $\mathrm{R}$ excluded are $\mathrm{R} 2$ of the endogenous latent variables obtained when the exogenous variables are included or excluded in the model. From the table above, it can be seen that the construct Y1 (Quality of service has a moderate effect on Y2 (Patient Recommendation).

\section{Hypothesis Testing.}

For hypothesis testing is done by looking at the probability value and the $\mathrm{t}$ statistic. For probability values, the p-value with an alpha of $5 \%$ is less than 0.05 . The $\mathrm{t}-$ table value for $5 \%$ alpha was 1985 . So that the criterion for acceptance of the Hypothesis is when the t-statistic> t-table. The research hypothesis testing was carried out by resampling, using the bootstrapping method. The number of bootstraps used in this study is 5000, according to Hair and Henseler's recommendations in Ghozali and Latan $(2015,80)$, the bootstrapping type chosen is no sign changes, test type and confidence interval method used is two tailed with level significance of $0.05(5 \%)$ and bias corrected and accelerated bootstrap.

Tabel 20.

\begin{tabular}{|c|c|c|c|c|c|}
\hline & $\begin{array}{c}\text { Original } \\
\text { Sample (0) }\end{array}$ & $\begin{array}{c}\text { Sample } \\
\text { Mean (M) }\end{array}$ & $\begin{array}{c}\text { Standard } \\
\text { Deviation (STDEV) }\end{array}$ & $\begin{array}{l}\text { T Statistics } \\
\text { (10/STDEVI) }\end{array}$ & P Values \\
\hline X1.Reliability (Kean dalan) $->$ Y1.Kualitas Pelayanan & -0.001 & -0.009 & 0.221 & 0.004 & 0.997. \\
\hline X2.Assurance (Jaminan) -> Y1.Kualitas Pelayanan & 0.368 & 0.364 & 0.243 . & 1.514. & 0.131 \\
\hline X3.Tangibles (Wu jud Nyata) $->$ Y1.Kualitas Pelayan an & 0.387 & 0.392 & 0.139 . & 2.784 . & 0.006 \\
\hline X4.Emphaty (Empati) -> Y1.Kualitas Pelayanan & 0.036 & 0.041 & 0.223 . & 0.163 . & 0.871 \\
\hline X5.Respon siveness (Ketanggapan) -> Y1.Kualitas Pelayanan & 0.082 & 0.092 & 0.154 & 0.534 & 0.593. \\
\hline Y1.Kualitas Pelayanan $\rightarrow$ Y2.Rekomendasi Pasien & 0.571. & 0.557 & 0.108 & 5.288 & 0.000 \\
\hline
\end{tabular}

Path Coefficients Mean. STDEV. T-Values, P-Values

The Bootstrapping table above shows that service quality has a positive effect of 5,288 on patient recommendations, and the relationship is significant at the 0.05 level, because the t-statistic value is greater than 1,985, which is 5,288. Tangibles (real form) have a positive effect of 2.784 on service quality, and the relationship is significant with a t value of 2.784> 1.985 .

Based on the data in the table above, a hypothesis can be tested as an answer to the formulation of the problem posed at the beginning of this study, namely as follows:

\section{Hypothesis test results 1 Reliability:}

Based on table 5.2, it can be seen that the respondent's response to reliability is an average of $55 \%$ percent strongly agree, $36 \%$ percent agree and $9 \%$ percent disagree and $1 \%$ strongly disagree. Reliability affects the quality of service at Pondok Indah
Bintaro Jaya Hospital. For this indicator, the t-statistical value for Reliability has an effect of 0.004 on service quality, the relationship is not significant at the 0.05 level and t-statistics> 1.985 which means that statistically Reliability has an effect but is not significant on service quality at Pondok Indah Bintaro Jaya Hospital.

\section{Hypothesis test results 2 Assurance:}

Respondents' responses to the Assurance indicator are shown in table 5.3. Respondents' responses to this indicator were on average $52 \%$ strongly agreed, $38 \%$ agreed, 9\% disagreed and there were $1 \%$ respondents who strongly disagreed. If you look at the average indicator score of 3.4 , it can be concluded that the patient strongly agrees with Assurance. Assurance (Guarantee) affects the quality of service at Pondok Indah Bintaro Jaya Hospital but not 
significantly. For this indicator, the $\mathrm{t}-$ statistical value for Assurance has an effect of 1.514 on service quality, the relationship is not significant at the 0.05 level and $\mathrm{t}$ statistics> 1.985 which means that statistically Assurance has no significant effect on service quality at Pondok Indah Bintaro Jaya Hospital.Hasil uji hipotesis

\section{Hypothesis test results 3 Tangibles:}

The responses of respondents to Tangibles (Real Form) are shown in table 5.4. Respondents' responses, namely $56 \%$ stated strongly agree, $39 \%$ percent agreed, $4 \%$ percent disagreed and there were $0 \%$ percent of respondents who said they were very dissatisfied. Tangibles (Real Form) affect the quality of service at Pondok Indah Bintaro Jaya Hospital. For this indicator, the t-statistics value for Tangibles (Tangibles) has a positive effect of 2.784 on service quality, the relationship is not significant at the 0.05 level and t-statistics> 1.985, which means that statistically Tangibles (Tangible Form) has a positive and significant effect. on quality at Pondok Indah Bintaro Jaya Hospital.

\section{Hypothesis 4 Empathy test results:}

Respondents' responses regarding Empathy (Empathy) namely 53\% strongly agree, $39 \%$ agree and there are $7 \%$ respondents who disagree. If you look at the average indicator score of 3.4 , it can be concluded that the respondent is satisfied with the empathy given by the nurse or admission. Empathy (Empathy) affects the quality of service at Pondok Indah Bintaro Jaya Hospital but not significantly. For this indicator, the t-statistics value for Empathy (Empathy) has an effect of 0.163 on service quality, the relationship is not significant at the 0.05 level and t-statistics> 1.985 which means that statistically Empathy has an effect and is not significant on service quality. at Pondok Indah Bintaro Jaya Hospital.

\section{Hypothesis test results 5 Responsiveness:}

Respondents' responses regarding responsiveness (responsiveness), namely $1 \%$ stated strongly disagree, $10 \%$ disagree, $45 \%$ agree and there are $43 \%$ of respondents who stated very satisfied. If you look at the average score of the indicator of 3.5, it can be concluded that the patient is satisfied with the responsiveness given by the hospital staff. Responsiveness (responsiveness) affects the quality of service at Pondok Indah Bintaro Jaya Hospital, but not significantly. For this indicator, the t-statistics value for Responsiveness has an effect of 0.534 on quality, the relationship is not significant at the 0.05 level and t-statistics> 1.985 which means that statistically Responsiveness has no significant effect on service quality.

\section{Hypothesis test results 6 Quality of service to patient recommendations:}

Based on the output, the research results show that service quality has a positive and significant effect on patient recommendations at the 0.05 level obtained from the t-statistics value with a $\mathrm{t}$ value greater than 1,985 ( $t>1,985)$ with a value of $\mathrm{t}=5,288$. This means that the better the quality of service provided by the Pondok Indah Bntaro Jaya Hospital, the better the patient's recommendation will be and vice versa. With more and more people recommending it, more and more patients can use the health services at this hospital. Indicators that contribute positively to service quality are indicators with an average value that exceeds the total average value of service quality such as; Tangibles (tangible form) to service quality, among others: Your doctor's appearance is quite good, your treatment room is comfortable, your treatment room facilities are functioning properly, and the cleanliness of rooms \& bathrooms is always maintained.

\section{Dominant Factors That Form Variable Constructs}

The discussion about the level of dominance that forms each latent variable 
construct can be determined by looking at the largest loading factor value for each indicator that forms the construct of the latent variable. In the Reliability construct, the biggest contribution to this construct is the X1.6 indicator regarding the nurse answering the patient's questions clearly, which is 0.853 . In Assurance, the indicator that gives the biggest contribution is $\mathrm{X} 2.5$. Patients feel confident and trust the nurse who handles them, with a loading factor value of 0.865 . In the Tangibles construct (tangible form) the biggest contribution to this construct is the X3.5 indicator regarding the cleanliness of rooms and bathrooms which are always maintained with a loading factor value of 0.897. In the Emphty (Empathy) construct, the biggest contribution to this construct is the $\mathrm{X} 4.7$ indicator regarding nurses hearing about patient complaints with a loading factor value of 0.846 . In the Responsiveness construct, the biggest contribution to this construct is the X5.10 indicator regarding the officer providing information about the procedure to be carried out properly with a loading factor value of 0.879 .

\begin{tabular}{lc}
\multicolumn{2}{c}{ Indirect Effects Total } \\
\hline \multicolumn{2}{c}{ Y2.Rekomendasi Pasien } \\
\hline X1.Reliability (Keandalan) & 0.000 \\
X2.Assurance (Jaminan) & 0.210 \\
X3.Tangibles (Wujud Nyata) & 0.221 \\
X4.Empathy (Empati) & 0.021 \\
X5.Responsiveness (Ketanggapan) & 0.047 \\
Y1.Kualitas Pelayanan & \\
Y2.Rekomendasi Pasien & \\
\hline
\end{tabular}

\begin{tabular}{lcc} 
& Direct Effect Total & \\
\hline & Y1.Kualitas Pelayanan & Y2.Rekomendasi Pasien \\
\hline X1.Reliability (Keandalan) & 0.000 & 0.000 \\
X2.Assurance (Jaminan) & 0.368 & 0.210 \\
X3.Tangibles (Wujud Nyata) & 0.387 & 0.221 \\
X4.Empathy (Empati) & 0.036 & 0.021 \\
X5.Responsiveness (Ketanggapan) & 0.082 & 0.047 \\
$\begin{array}{l}\text { Y1.Kualitas Pelayanan } \\
\text { Y2.Rekomendasi Pasien }\end{array}$ & & 0.571 \\
& Source: Processed data \\
\end{tabular}

Based on the indirect effect table above, the indicator that has the greatest value on (Y2) the patient's recommendation is (X3) Tangibles (real form) with a value of 0.221 significance. This indicates that patients who recommend services at Pondok
Indah Bintaro Jaya Hospital are satisfied with the services provided, especially on the Tangibles indicator (Tangible).

For the direct effect table, the indicators that have the greatest value on (Y1) service quality and (Y2) patient recommendations are: (X2) Assurance with a value of 0.368 against (Y1) service quality and a value of 0.210 against (Y2) patient recommendations. (X3) Tangibles with a value of 0.387 against (Y1) service quality and a value of 0.221 against (Y2) customer recommendations.

In addition, there are 3 indicators that have no significant effect, namely: (X1) Reliability with a value of 0.000 on (Y1) Service Quality which also affects (Y2) Patient Recommendations with a value of 0.000. (X4) Empathy (Empathy) with a value of 0.036 against (Y1) Service Quality which also affects (Y2) Patient Recommendations with a value of 0.021 . (X5) Responsiveness (responsiveness) with a value of 0.082 to (Y1) Service quality affects (Y2) patient recommendations with a value of 0.047 .

Among the 5 indicators above, there is one more indicator that has the greatest value on (Y2) Patient Recommendations, namely (Y1) service quality with a value of 0.571 .

Based on the table above, it can be seen that patients who recommend the hospital are satisfied with the services provided, especially in terms of assurance and tangibles. However, overall that (Y1) Service Quality has a positive or significant direct effect on (Y2) patient recommendations with a value of 0.571 . This is the same as the research results of Sutawijaya, Muchtar, and Nawangsari, that to improve the quality of certification service in the use of SNI marks, the steps that need to be done by the management on the basis of matrix gap score is to form a comprehensive strategic plan, which due to the interrelation between each attribute it is not possible to do remedial action Countermeasure independently of each of these attributes. 


\section{DISCUSSION}

Provide input to the management of Pondok Indah Hospital regarding inpatient satisfaction with the services provided and as a basis for periodic evaluation of the quality assessment of services provided as well as consideration in order to determine policies and decision making regarding services provided by the hospital. Adding scientific studies about patient satisfaction regarding services at Pondok Indah Hospital and contributing theoretical thoughts and information, for the application and development of the discipline of science in economics, especially operational management for enthusiasts and further researchers to develop more in-depth research.

\section{CONCLUSION}

Based on hypothesis testing and discussion of research results, the following research results can be stated:

1) Reliability affects the quality of service at Pondok Indah Bintaro Jaya Hospital. For this indicator, the t-statistical value for Reliability has an effect of 0.004 on service quality, the relationship is not significant at the 0.05 level and $t-$ statistics >1.985 which means that statistically Reliability has an effect but is not significant on service quality. .

2) Assurance (Guarantee) affects the quality of service at Pondok Indah Bintaro Jaya Hospital but not significantly. For this indicator, the tstatistics value for Assurance has an effect of 1.514 on service quality, the relationship is not significant at the 0.05 level and t-statistics >1.985, which means that statistically Assurance has no significant effect on service quality.

3) Tangibles (Tangible Form) affect the quality of service at Pondok Indah Bintaro Jaya Hospital. For this indicator, the t-statistics value for Tangibles (Tangibles) has a positive effect of 2.784 on service quality, the relationship is not significant at the 0.05 level and tstatistics> 1.985, which means that statistically Tangibles (Tangible Form) has a positive and significant effect. on quality at Pondok Indah Bintaro Jaya Hospital.

4) Empathy (Empathy) affects the quality of service at Pondok Indah Bintaro Jaya Hospital but not significantly. For this indicator, the t-statistics value for Empathy (Empathy) has an effect of 0.163 on service quality, the relationship is not significant at the 0.05 level and tstatistics> 1.985 which means that statistically Empathy has an effect and is not significant on service quality at Pondok Indah Bintaro Jaya Hospital.

5) Responsiveness affects the quality of service at Pondok Indah Bintaro Jaya Hospital but not significantly. For this indicator, the t-statistics value for Responsiveness has an effect of 0.534 on quality, the relationship is not significant at the 0.05 level and $t-$ statistics >1.985 which means that statistically Responsiveness has no significant effect on service quality.

6) Quality of service, based on the output of the research results show that service quality has a positive and significant effect on patient recommendations at the 0.05 level obtained from the t-statistics value with a $t$ value greater than 1,985 ( $t>1,985)$ with a value of $t=5,288$. This means that the better the quality of service provided by the Pondok Indah Bntaro Jaya Hospital, the better the patient's recommendation will be and vice versa.

\section{REFERENCES}

1. Muninjaya, A.A.G. 2011. Manajemen Mutu Pelayanan Kesehatan. Jakarta: EGC

2. Brysland, A. \& Curry, A. (2001). Service Improvement in Public Services Using SERVQUAL. Managing Service Quality.

3. Rambat Lupiyoadi. 2013. Manajemen Pemasaran Jasa, 2 ed. Jakarta: Salemba Empat

4. Tjiptono, Fandy. 2012. Service Management Mewujudkan Layanan Prima, Edisi Kedua. Yogyakarta. Penerbit Andi 
5. Parasuraman, A., Zeithalm, V., dan Berry L., 1988. SERVQUAL: A Multiple Item Scale for Measuring Consumer Perceptions of Service Quality, Journal of Retaliling.

6. Kadek Brahma Shiro Wididana, Analysis of the Effect of Service Quality on Quality and Patient Trust in Shanti Graha Buleleng General Hospital" (2017) https://www.ejournal.warmadewa.ac.id/inde x.php/jagaditha/article/view/125

7. Ghozali, Imam. 2014. Structural Equation Modeling: Metode Alternatif dengan Partial LeasSquare (PLS) Edisi 4. Semarang: Badan Penerbit Universitas Diponegoro

8. Sugiyono. 2013. Metode Penelitian Kombinasi. CV Alfabeta. Bandung

9. Buchory, Acmad Herry \& Saladin Djaslim. (2010). Manajemen Pemasaran, EdisiPertama. Bandung. Linda Karya.

10. Hair, J.F., Black, W.C., Anderson, R.E., and Tatham, R.L., (2010), Multivariate Data Analysis, Fifth Edition $\left(7^{\mathrm{TH}}\right.$ Edition), Prentice Hall, Upper Saddle River, New Jersey.

11. Hair, Jr, Joseph. 2009. Multivariate Data Analysis 9 ed. New Jersey: Pearson Education.

12. Hertanto, Eko. 2017. Metode Penelitian: Perbedaan Skala Likert Lima Skala dengan modifikasi skala likert emapt skala. Jakarta.

13. I. S. Pohan, Jaminan Mutu Pelayanan Kesehatan: DasarDasar Pengertian Dan Penerapan. Jakarta: Egc, 2004.

14. Indriani, P., \& Sugiarti, I. (2014). Gambaran Effisiensi Penggunaan Tempat Tidur Ruang Perawatan Kelas III Di Rumah Sakit Umum Daerah. Jurnal Manajemen Informasi Kesehatan Indonesia, 2(1), 2010- 2015.

15. Kotler, Philip and Kevin Lane Keller. 2016. Marketing Management 15. Pearson Education, Inc.

16. Kuncoro, A. E. \& Riduwan. (2008). Cara Menggunakan dan Memaknai Analisis Jalur (Path Analysis). Bandung: Alfabeta.

17. M. Magdalena, S. Arto, And R. Ginting, "Peningkatan Kualitas Pelayanan Dengan Menggunakan Metode Quality Function Deployment (Qfd) Di Rumah Sakit Xyz," Vol. 3, No. 2, Pp. 31-37, 2013.

18. Menteri Kesehatan, "Peraturan Menteri Kesehatan Republik Indonesia Nomor 11 Tahun 2016 Tentang Penyelenggaraan
Pelayanan Rawat Jalan Eksekutif Di Rumah Sakit," 2016.

19. Menteri Kesehatan Republik Indonesia, "Keputusan Menteri Kesehatan Republik Indonesia Nomor 560/Menkes/Sk/Iv/2003 Tentang Pola Tarif Perjan Rumah Sakit Menteri," P. 11, 003. Dirjen Yanmed Depkes Ri, "Standart Pelayanan RumahSakit," 1999.

20. Norazah Mohd Suki, Norbayah Mohd Suki. Service Quality Vs. Customer Satisfaction: Perspectives of Visitors To A Public University Library. Journal World Academy of Science, Engineering And Technology 74 2013

21. Ringle, Christian M., Wende, Sven, \& Becker, Jan-Michael. (2015). SmartPLS 3. Bönningstedt: SmartPLS. Retrieved from http://www.smartpls.com

22. R. R. Ranas, "Analisis Dan Perbaikan Layanan Hotel Menggunakan Servqual Dan Diagram Kartesius (Studi Kasus Di Hotel Kombokarno)," Vol. 14, Pp.119-132, 2013.

23. Sangadji, Etta Mamang Dan Sopiah, Perilaku Konsumen, Yogyakarta:CV Andi Offset, 2013.

24. Sanusi, Anwar. 2014. Metodologi Penelitian Praktis Untuk Ilmu Sosial dan Ekonomi. Edisi Pertama. Cetakan Pertama. Penerbit Buntara Media, Malang.

25. Sirs. Kemkes, http://sirs.yankes.kemkes.go.id/rsonline/data _list.php?pagesize $=30$ Supranto, J. (2010) Statistika. Jakarta: Erlangga.

26. Santoso, Singgih, Structural Equation Modelling; Membuat dan Menganalisis Model SEM Menggunakan Program AMOS, Elex Media Komputindo, Jakarta 122 Jurnal IPTEK Vol.16 No.2 Desember 2012

27. A.H. Sutawijaya, I.L. Mochtar, L.C. Nawangsari, Quality Certification and Customer Satisfaction, European Research Studies Journal, Volume XXI, Issue 3, 2018 pp. $266-279$

How to cite this article: Imaroh TS, Nurida N. Analysis of quality factors of service to patient recommendations at Pondok Indah Bintaro Jaya Hospital. International Journal of Research and Review. 2021; 8(3): 36-50. 